\title{
INFORMALITY AS POLITENESS STRATEGIES IN REQUEST OF ENGLISH EDUCATION STUDY PROGRAM OF RIAU ISLANDS UNIVERSITY
}

\author{
Suswanto Ismadi Megah S. \\ Prodi Pendidikan Bahasa Inggris Universitas Riau Kepulauan, Batam, Indonesia \\ megah76@yahoo.co.id
}

\begin{abstract}
This study was aimed to identify the informality of request as politeness strategies used by the students of English Education study Program (English department) of Unrika Batam.The data was obtained from request spoken by the student of English department students. The data taken based on cluster sampling due the homogeneous data. The data was students of morning class of semester seven. This study concluded that The usage of bu, ma, mah (means mother) five data and yah, pak, and pa (means father or daddy), the speaker respects to the hearer's face by addressing her as mom. This considered her position is upper position; this does not threaten her face. This is used informally to her mother in relaxed situation. The usage of imperative sentences are four data when the hearer asks her young sister to take the glass, then the subject asks her big sister to buy her dress, when she asks her young sister to take chilly and when the subject ask the money to pay rental house. This sentences forces her face's hearer. This shows negative face. The last is speaker states "adek" young sister to her father means to soften request to her father due to the father will usually fulfill the young child.
\end{abstract}

Keywords : Informality, request, politeness strategies and students.

\section{INTRODUCTION}

Communication is normally known as two traffic speaking way between speaker and hearer. It make understand between speaker and hearer How meaning is communicated through a particular language reflects the speaker's identity and culture. Jamaliah (1995:32) adds that communication, therefore, allows members of a culture to act and show evidence of thinking, attitudes, beliefs and values that is appropriate to that culture, and in so doing they provide a background for understanding each other. Thus, communication within a particular group sharing the same language, cultural and social values will demonstrate communication features which are appropriate to a particular group and understood by all its members. In this sense, 
group members of different social status share and understand the same communication style and features, whether they are lawyers, housewives, students or prostitutes.

Politeness may occur in teaching learning process from elementry school until university. The students has specific politeness in the classroom. It may occur in the college of education which create new teacher, this may identify how teacher candidates give informality to request to their lecturer.

Politeness as strategy used by students in request something in order the request fulfilled, so, the students use politeness strategy in the classroom is one of the topics that seem almost too obvious to mention; of course, people will be polite in a classroom, just as they're polite in a place of worship or at a job interview. But, the classroom is a bit different; it has its own rules of politeness. And, to complicate matters just a bit, these rules are modified in various ways by different institutions and by different instructors or lecturers. Therefore, the same rules of politeness done in the classroom as in Japan, Russia, or Saudi Arabia as well in Indonesia, particularly in Batam, Riau islands Province.

Hastuti (2011) states that request for action and request for permission are mostly employed by the speakers. There are seven data that belong to request for action and six data that belong to request for permission. Then, the act of offer is expressed twice by the speakers.

Request for action and request for permission a Request for action and request for permission are mostly employed by the speakers. There are seven data that belong to request for action and six data that belong to request for permission. Then, the act of offer is expressed twice by the speakers Request for action and request for permission are mostly employed by the speakers. There are seven data that belong to request for action and six data that belong to request for permission. Then, the act of offer is expressed twice by the speakersre mostly employed by the speakers. There are seven data that belong to request for action and six data that belong to request for permission. Then, the act of offer is expressed twice by the speakers. As stated in the dictionary reverse that "Informal speech or behaviour is relaxed and friendly rather than serious, very correct, or official. An informal situation is one which is relaxed and friendly and not very serious or official"., 


\section{UNDERLYING THEORY}

\section{The concept of Face}

This concept of face emerged about face stated by Goffman (1967), in effective interaction, people have their own and their interlocutor's face to consider. Brown and Levinson (1987:13-15) explain that the notion of face and its constituents are applicable in cross-culturally society. In other words, they propose that the strategies employed in the construction and maintenance of face in an interaction via politeness is universal because this is applicable in all languages. Thus, each human being needs to be to have his face respected and maintained in public. As a human being the students have similar needs - to preserve either her own face and to make an effort to preserve her client's face during communication. This concept also used in request by the students to avoid face 'fall'.

Brown and Levinson (1987) distinguish between two types of face: positive face and negative face. The positive face is a person's want to be appreciated while the negative face is the person's want to be free of imposition or force. Brown and Levinson also propose the theory of 'Face threatening Acts' (FTAs). Strategies under this theory are used to minimize threat on interlocutors' face. These strategies are bold on record, positive politeness, negative politeness, off-record indirect and don't do the FTA.

\section{Politeness Theory}

Brown and Levinson (1987) propose the Universal Politeness Theory as an improvement of the ideas from Grice's and Leech's Maxims. The Universal Politeness Theory is based on conversational practices of three ethnic communities, involving three unrelated and quite different languages, English, Tamil and Tzeltal. Each of these languages demonstrates similarities in the way its respective speakers apply strategies to show politeness in rational communication.

Within this Universal Politeness Theory, Brown and Levinson (1987:58) make reference to the Model Person (MP) who is a fluent speaker of a natural language and who possesses two special properties -- rationality and face; and has "the power of making conscious decision and deliberate choice of action" (Jamaliah, 1995:26) Brown and Levinson (1987:63) further 
explain that there are two kinds of 'face-wants': positive face and negative face. During interaction the interlocutors are seen as actively and deliberately constructing utterances which are either face-saving or face threatening. In a rational communication both the Speaker as well as the Hearer aim at reducing speech acts which threaten face. This according to Brown and Levinson is done through the use of specific strategies known as face threatening acts (FTAs). In other words, politeness strategies are used during conversation to keep face safe, and to avoid the risk of the loss of face. Therefore, each speaker should use appropriate strategies which are able to lessen the FTAs.

\section{Request}

Hastuti (2011) the usage of request was influenced by the politeness strategies of the Brown and Levinson's theory of politeness. While Searle (1969: 16) defined speech acts as "the basic or minimal units of linguistic communication," which could be analyzed on three levels (Austin, 1969): the locution (the linguistic utterance of the speaker), the illocution (what the speaker intends) and perlocution (the eventual effect on the hearer). The study of speech acts in ILP has concentrated on illocutionary meanings (Ellis, 1994). Searle (1979) had put forward a taxonomy of illocutionary acts which were further elaborated by Yule (1996), including directives, commissives, expressives, representatives and declarations. Among them, directives are those speech acts whose function is to get the hearer to do something. As attempts on the part of a speaker to get the hearer to perform or stop performing some kind of action (Ellis, 1994), requests are therefore labeled as directives. In addition, social factors such as social distance, social power and the degree of imposition interacted with age and sex in determining the choice of request strategies;

\section{Informality}

Informality is usually known as not serious expression or speech. Normally people speak informally with closed friend, intimacy friends. Informality is aimed to show informality. Thus, informal is categorized something done not so seriously. It is based on formal and informal language so, informal language is characterized by a simpler grammatical 
structure (i.e. loosely-connected sentences and phrases), and personal evaluation. According to Hastuti (2011) the usage of informality was influenced by the politeness strategies of bold on record of the Brown and Levinson's theory of politeness. Informal language may make use of slang and colloquialisms, employing the conventions of spoken language. However, it is too casual and loose to be acceptable for academic writing.

According to Holmes (2008) Formality increases between participants (speaker and hearer) when the social distance is greater. Informality (Solidarity) increases when the social distance is little between participants (speaker and hearer). While social status depends on a number of factors such as social rank, wealth, age, gender and so on; therefore the person with the higher social status has the choice of using formality or informality (solidarity) when addressing other persons of lower social status. But the person with the lower social status uses only formality when addressing a person of higher social status.

\section{METHODOLOGY}

The methodology used in this research is qualitative research using case study approach. Bogdan and Taylor in Moleong (2006: 4) defines that qualitative method as a research procedure that produces descriptive data in the form of written or oral words of people and behavior that can be observed. Case studies are research strategies that researchers carefully investigate a program, event, activity, process, or group of individuals. Cases are limited by time and activity, and researchers collect complete information using various data collection procedures based on predetermined time (as quoted in Creswell 2010: 20). The data was obtained from request spoken by the student of English department students. The data taken based on cluster sampling due the homogeneous data. The data was students of morning class of semester seven, the data obtained when they requested something from her/his closed people around her such as family and classmate. Therefore, it can be described that the case study approach is more focused on a case, the case referred to in this research is the impact in informality of request in politeness theory 


\section{FINDINGS}

The data finding was based on the request of the subjects (English department students of Unrika) who request with their closed persons. The data analyzed qualitatively. the data discussed as follows:

\section{Data 1}

\section{"bu Sepatu ini bagus"}

This was done by the subject who went to a mall in her town. She dropped at a shoes shop. Then she said "bu Sepatu ini bagus" ( this shoes is good). This is aimed to have her mother to buy it for her, but her mother just smiles.

\section{Data 2}

\section{"ma, bagus kan ma"}

This was said when the subject took a walk to Botanical plaza to buy daily needs such as vegetables, ruce, sugar, etc., with her mother. Then she found a dress seller who sells beautiful dress. Then she said " ma, bagus kan ma" (mom, this is good, mom). This is aimed to have her mother to buy it for her, but her mother just answered "mau ya? (you want?).

\section{Data 3}

\section{"sore bu, maaf saya mau tanya"}

This was said when the subject asked to her lectuer to have permission cannot follow her lecture. Then she said "sore bu, maaf saya mau tanya" (evening, sorry I will ask?). This is aimed to have permission from the lectuerer, the lecturer answered "gak papa" ( it is okay).

\section{Data 4}

\section{"ambilkan gelas itu"}

This was done by the subject who asked to her sister that she wants her to take a glass. Then she said "ambilkan gelas itu" ( take the glass). This is aimed to have her sister follow her order to take the glass.

\section{Data 5}




\section{"Kak , belikan baju ini, cantik kan?"}

This was said when the subject took a walk to a mall, with her big sister. Then she found a dress seller who sells beautiful dress. Then she said "Kak, belikan baju ini, cantik kan?" (sis, this is dress is so beautiful, buy it. This is aimed to have her big sister to buy it.

\section{Data 6}

"mah, uang ujianya 200ribu"

This was said when the subject requested a tuition fee to pay examination payment. Then she said " ma,uang ujianya 200ribu" (mom, exam fee 200 thousands). This is aimed to request money to pay her examination fee amount 200 thousands.

\section{Data 7}

\section{"sudah waktunya bayar kost"}

This was said when the subject requested to his cousin to pay rental house (kost). Then he directly said "sudah waktunya bayar kost" (this is time to pay rental houses). This is aimed to request money to pay rental houses directly.

\section{Data 8}

\section{"Wati ambilkan cabe"}

This was done by the subject who asked to her sister that she wants her to take chilly. Then she said "ambilkan cabe" (Wati, take chilly). This is aimed to have her sister follow her order to take the chilly.

\section{Data 9}

\section{"yah, Sepatu sudah rusak"}

This was done by the subject who went to a mall in her town with her father. She dropped at a shoes shop. Then she said "yah, sepatu adek sudah rusak" ( dad, my shoes was broken). This is aimed to have her father to buy it for her. 


\section{Data 10}

\section{"mah, epi butuh laptop"}

This was done by the subject who needs a laptop to fulfill her assignment, therefore, she wants her mother to buy it by saying "mah, epi butuh laptop" ( mom, Epi needs laptop), it means she wants her mother to buy a laptop for her.

\section{Data 11}

\section{"adek mau itu"}

This was done by the subject who went with her family to a mall in her town. She dropped at a shoes Then she said "adek mau itu" ( young sister wants that). This is aimed to have her mother to buy something in the shop.

\section{Data 12}

\section{"pak, hp saya mulai rusak"}

This was done by the subject who wants a new handphone. Then she said "pak, hp saya mulai rusak" ( dad, my handphone is going to be broken). This is aimed to have her father to buy new handphone for her.

\section{Data 12}

"ad, ko"

This was done by the subject who wants a meale. Then he said "ad ko ( is there anymeal). This is aimed to have her father to buy new handphone for her.

\section{Data 13}

\section{"pak, kantong saya mulai rusak"}

This was done by the subject who wants a new dress. Then he said "pak, kantong saya mulai rusak" ( dad, my pocket is going to be broken). This is aimed to have her father to buy new dress for him. 


\section{CONCLUSION}

The data found that the usage of informality was influenced by the politeness strategies of bold on record of the Brown and Levinson's theory of politeness. Informal language may make use of slang and colloquialisms, employing the conventions of spoken language. However, it is too casual and loose to be acceptable for academic writing. In addition, usage of request was influenced by the politeness strategies of the Brown and Levinson's theory of politeness. Face must be considered because of request. As the notion of face and its constituents are applicable in cross-culturally society. While informality shows intimacy between the speaker and the hearer. Here the subject as the speakers to request something informally.

This study concluded that The usage of bu, ma, mah (means mother) five data and yah, pak, and pa (means father or daddy), the speaker respects to the hear's face by addressing her as mom. This considered her position is upper, this does not threatens her face. This is used informally to her mother in relaxed situation.

The usage of imperative sentences are four data when the hearer asks her young sister to take the glass, then the subject asks her big sister to buy her dress, when she asks her young sister to take chilly and when the subject ask the money to pay rental house. This sentences forces her face's hearer. This shows negative face. The last is speaker states "adek" young sister to her father means to soften request to her father due to the father will usually fulfill the young child.

\section{BIBLIOGRAPHY}

Baskaran, Loga. 2005 Linguistics Primer Kuala Lumpur: Press.

Brown, Penelope and Levinson, C. Stephen.1987. Politeness: Some Universals in Language Usage. United Kingdom: Cambridge University Press.

Cresswell, J.W. (2010). Research Desain : Pendekatan Kualitatif, Kuantitatif, dan Mixed. Yogyakarta : Pustaka Pelajar. 
Suswanto: Informality as Politeness Strategies................

Goffman, Erving.1981. On Face-Work: An Analysis of Ritual Elements in Social Interaction.Psychiatry, 18: 213-31.

Grice, H.P. 1975. "Logic and Conversation", Syntax and Semantics, Speech Act, 3, New York: Academic Press.

Moleong, J.L. 2006. Metodologi Penelitian Kualitatif. Bandung : PT Rosdakarya

Holmes, Janet. 2001. An Introduction to Sociolinguistics. London: Longman.

Leech, G. N. 1983. Principles of Pragmatics. New York: Longman.

Levinson, Stephen C. 1983. Pragmatics. London: Cambridge University Press.

Hastuti, Yuni. 2011.Politeness strategies in request in the Movie Sydney white. Thesis. Uns.

https://www.tes.com/.../formal-vs-informal-language-6069532

http://dictionary.reverso.net/english-cobuild/informal\%20request 10/05/17 